\title{
Rødbeter er sunt og godt
}

De herlige rotgrønnsakene er gode som pannestekte, syltede, kokte, urtebakte, saltbakte, moste og gratinerte. Kokte rødbeter med nypoteter, smør og gressløk, bakt rødbetesalat med lun chèvre og honning eller valnøtter, rødbetehummus, rødbetesuppe med appelsin og rødbeter kokt i appelsinjuice og servert med pannestekte kamskjell og sprøstekt bacon ... Fristelsene er mange, og i tillegg er de røde! Pasientene i denne artikkelen trodde de hadde fått blod i urinen, men legen kunne berolige dem med at den røde urinen skyldtes rødbetespising (Tidsskr Nor Legeforen 1942; 62: 363-66).

\section{Oversikter.}

\author{
Erik Jacobsen: Rød Urin efter Spisning af Rødbeder. Anthocyanuri.
}

(...) Fargestoffet i rødbeter (rabis vulgaris rubra) hører til den gruppe av plantefargestoffene som kalles anthocyaner, og som først ved Willstätters undersøkelser (1913) er blitt nærmere kjent. Anthocyanene er glykosider, som ved innvirkning av enzymer eller ved oppvarming med syrer, spaltes til sukkerarter (oftest glykose eller galaktose) og anthocyanidiner. Av de siste er pelargonidin, cyanidin og delphinidin de viktigste; de er for øvrig i kjemisk henseende meget nært beslektet. Pelargonidinklorid har følgende konstitusjonsformel:<smiles>O=C(O)C1C(O)CC(O)CC1C1CCC(O)CC1</smiles>

(...) Pasientene henvendte seg til læge da de trodde det var blod i urinen. Av anamnestiske opplysninger og kliniske funn skal anføres:

1. $2 \frac{1}{2}$ år gl. gutt. 2 dager tidligere blodrød urin. I går var fargen svakt rød. Status præsens: Urin: albumin eller puss kan ikke påvises. Ved mikroskopi sees noen røde og hvite blodlegemer samt tallrike krystaller.

Det opplyses at gutten hadde spist rødbeter dagen før urinen blev rød.

2. 28 år gl. gift kvinne. Opplyser at urinen var blodrød i potten. Foruten henne selv har hennes mann (33 år) og 3 barn på 5, 4 og 3 år også hatt rødfarget urin i 3-4 dager. Familien har spist nedlagte rødbeter, som angivelig skulde være av en særlig mørkerød art, av en krukke som rommet 71.

Lægen fortalte pasienten at urinens farge skyldtes rødbetene. Familien fortsatte å spise til krukken var tom, hvilket tok 10 dager. Urinen var rød hele tiden; men fargen forsvant da det var slutt på rødbetene.

3. 10 år gl. gutt. Blodrød urin om morgenen. Senere samme dag er den samme prøve bare lett bronsefarget. Det finnes ikke puss eller eggehvite, og de mikroskopiske funn er normale. Ved tilsetning av kalilut forandres fargen til gul.

Gutten var meget glad i rødbeter og hadde spist en hel rødbete av den mørkerøde sort dagen før. Forfatteren lot gutten spise rødbeter også neste dag, og urinen ble igjen rød.

4. $21 / 3$ år gl. pike. Foregående dag spiste barnet en kokt rødbete så stor som et lite eple. $8 \mathrm{t}$. etterpå rød urin. Urinen viste ved mikroskopi noen bakterier samt røde og hvite blodlegemer. Urinen var rødfarget hele $30 \mathrm{t}$. etter inntagelsen av rødbeten, hvilket er den lengste varighet for fargeutskillelse etter en enkelt inngift, som forfatteren har sett. Urinen ble for øvrig undersøkt på hematoporfyrin med negativt resultat.

$$
\text { (...) }
$$

